\title{
New Directing Voices in South African Cinema
}

\author{
By Martin P. Botha \\ Spring 2005 Issue of KINEMA

\section{NEW DIRECTING VOICES IN SOUTH AFRICAN CINEMA: GRADUATES FROM FILM SCHOOLS}

\section{Introduction}

Although 1994 saw the birth of democracy in South Africa our film industry is much older; in fact, our great documentary film tradition dates back to 1896 and the Anglo Boer War. ${ }^{(1)}$ While celebrating the past ten years of democracy we shouldn't forget those filmmakers, who created films against all the odds. Jans Rautenbach (Jannie Totsiens) ${ }^{(2)}$, Ross Devenish (Marigolds in August) ${ }^{(3)}$ and the younger generation of the 1980s challenged moral and political censorship, a severe lack of audience development and inadequate film distribution to shape progressive texts, which became the foundation of a new, critical South African cinema during the 1990s.

Publications by Balseiro and Masilela (2003), Botha and Van Aswegen (1992), Blignaut and Botha (1992), Botha and Dethier (1997), Davis (1996), Gutsche (1972), Louw and Botha (1993) and Tomaselli (1989) documented developments in South African cinema in detail. A critical overview of the fragmentation of the South African film industry during apartheid is presented in Schelfhout and Verstraeten's publication De rol van de media in de multiculturele samenleving (1998), as well as in Botha (1997, 2003a, 2004). The painful reality of South African filmmaking between 1895 and 1994 was that, in many ways, black South Africans were excluded. Black South Africans had no money to make films. They had no access to equipment. Opportunities were almost non-existent for black scriptwriters or directors to create their own images on the screen. And apartheid policy led to a very fragmented film industry (see Botha 2004).

Post-apartheid cinema is characterized by the emergence of new voices in our film industry. One thinks of a new generation of filmmakers such as Zola Maseko (The Life and Times of Sara Baartman, Mr Drum); Ntshavheni Wa Luruli (Chikin Biznis - The Whole Story, The Wooden Camera); Akin Omotoso (God is African); Teboho Mahlatsi (Portrait of a Young Man Drowning, Yizo Yizo); Dumisani Phakhati (Christmas with Granny, Waiting for Valdez); Ramadan Suleman (Fools, Zulu love letter); Sechaba Morojele (Ubuntu's Wounds); Gavin Hood (A Reasonable Man); Zulfah Otto Sallies (Raya); Riaan Hendricks (A Fisherman's Tale); Khalo Matabane (Chikin Biz'nis); Jason Xenopoulos (Promised Land); Madoda Ncayiyana (The Sky in Her Eyes) and Norman Maake (Soldiers of the Rock).

For the first time South African audiences are exposed to certain marginalized communities, such as the homeless in Francois Verster's remarkable documentary Pavement Aristocrats: The Bergies of Cape Town (1998), the Himbas of Kaokoland in Craig Matthew's Ochre and Water (2001), AIDS victims in Shouting Silent (2001), the gay subcultures of the fifties and sixties in The Man Who Drove With Mandela (1998) and the San Bushmen in the Foster Brothers' visual poem The Great Dance (1999).

With local formal film training providers mushrooming since the 1990s, some very interesting work has been produced from the directing graduates. In many ways there is more originality and an ability to explore the potential of the medium on display in the short films of these upcoming directors than in an entire decade of local filmmaking in the 1970s!

Film schools have become vital in a post-apartheid South African cinema to expose students to international cinema, as well as to focus on the technological, social, aesthetical and political highlights in the development of cinema in all its facets. Apart from skills training, South African film schools have the responsibility to nurture new voices in an industry which has a long history in which many voices were silenced - those from the black majority, women, gays and lesbians. ${ }^{(4)}$ Film is not only for getting bums on seats, but also a means of self-expression by voices, which were silent during the apartheid years. Those voices could belong to blacks, women, gays and lesbians, and others, who never had the opportunity to express themselves in the cinema under apartheid. 
In this overview of new directing voices in post-apartheid cinema I have focused on directors who graduated from South African film schools recently, or were associated with a formal training institution. The choices are based on the fact that these people have impressed international and national adjudicating panels with their work, which in many cases have resulted in awards. I have also broaden the focus to include graduates, who returned from international film schools or who are associated with local training providers.

\section{THE NEW VOICES}

\section{Dean Blumberg}

When I first saw Black Sushi as part of the adjudicating panel of the 2003 Apollo Film Festival ${ }^{(5)}$ I was immensely impressed by the sensitivity and delicate handling of the subject matter. Here is the story of a black male, Zama, whose old comrades immediately try to draw him back into the criminal world after he is released from prison. Caught up in the cyclic nature of crime and punishment Zama's life seems headed for the same unfortunate conclusion until he becomes attracted by the mysterious art of Sushi making. It is a stroke of genius that Blumberg pulls off this narrative device and in the end the short film becomes a beautiful meditation on cultural identity and multicultural communication, for which it deservedly won a special award at the $14^{\text {th }}$ African, Asian and Latin American Film Festival in Milan.

After several years as a production assistant while successfully finishing a Bachelors Degree in Commerce at the University of the Witwatersrand, Blumberg enrolled at AFDA (The South African School of Motion Picture Medium and Live Performance), where he completed both a Bachelors and Honours Degree in Motion Picture Medium. More important, his talent is on display in a few short films, which have won numerous international and national awards. Black Sushi was chosen as the Best Student Film at the 2003 Apollo Film Festival. It was also screened as part of the 10 Years of Freedom Festival in New York in May 2004. It toured several festivals around the world, from Manchester to Mexico City.

Even more impressive, if judged by international critical acknowledgment, is Under the Rainbow, a poetic recreation of actual events, which took place in the inner city of Johannesburg. It is a story of two young men on their nightly prowl, which inevitably turns tragic. In Blumberg's own words the film is about "people under the rainbow. There were a lot of people that got left behind" in the new South Africa. "They didn't go over the rainbow - they got left underneath it." ${ }^{(6)}$ In a blending of cinéma vérité and poetic realism the film is a gritty portrayal of contemporary urban South Africa, a meditation on the dreams of a dismembered sector of our population and their inevitable search for a better life. The film won numerous awards, including the Fiction Award at the Short Ends World Film Schools Festival in London and a Certificate of Mention at the $7^{\text {th }}$ International Festival of Film Schools in Mexico City.

Unlike France and Poland where graduates from film schools have a better chance to move into the film industry as young directors (Kieślowski is a very good example) our directing graduates are very much out in the cold after they have left the safe environments. In a way they are marginalised and the opportunities to obtain hands-on experience on longer formats such as features are limited. Blumberg at present is working for a production company, Freshwater Films, and will be working on commercials. Over the past year he worked on three feature film scripts, one being a full length version of Black Sushi. He is also working on a documentary rooted in the sub cultures of Johannesburg. So far his film images consist of looking at the urban landscape of that city, with all its angst, but also of hope and even optimism. He also has secured plans to shoot a low budget DV film later this year.

\section{Harold Holscher}

At the $25^{\text {th }}$ Stone Awards Evening of the National Television and Video Association (NTVA) in 2003, Holscher's short iBali not only picked up a Stone Award for overall excellence, but garnered craft awards for directing, acting, cinematography and animation. The film is a magnificent blending of magic realism and African mythology, with touches of the urban alienation of Antonioni (Holscher is an admirer of Zabriskie Point), the surrealism of Mambety and the beautiful compositions of Kubrick. Holscher states that iBali "came from an idea of living one's heritage, one's culture." He is fascinated by myths and fables, especially in the cinemas of Mambety and Kusturica. The plot of $i B a l i$ conveys how African heritage is passed from generation to generation through the art of story telling. It is a mythical tale about a boy discovering the essence of water. 
The film is one of the first from a local film school, which actually explores the possibilities of orality in South African film narrative. It aims at an indigenous mode of aesthetics and judged by the national and international recognition, seems to succeed. iBali was selected for the $14^{\text {th }}$ African Film Festival in Milan and forms part of the best of the shorts compilation, which will be screened in other Italian cities after the festival. It has been selected for the Commonwealth Film Festival in Manchester and also toured the United Kingdom as part of the best of the festival. It was invited to the $7^{\text {th }}$ Genova Film Festival, as well as the 2004 Cape Town World Cinema festival.

Holscher graduated from the CityVarsity Film, Television and Multimedia School with a list of awards that testify to his talent. During 2002 his experimental musical narrative In Progress won awards for directing and the overall production. In the same year he received awards for 'n Sprokie, another "fairytale like $i B a l i "$, characterized by exquisite visuals (another craft award), shot on $16 \mathrm{~mm}$. Adapted from an Afrikaans story it tells the sad tale of a woman waiting for her son to return from the war in Angola, but he will never return and the war has been lost...

The way ahead, after film school, is uncertain for Holscher. In December 2003 he had the opportunity to do the storyboards for a Xhosa language production of Carmen $^{(7)}$ in Cape Town. As in the case of Blumberg he is working on feature length scripts. He doesn't consider himself to be a very good writer: "The ideas are in my head. I just can't put it down on paper. I have to paint them, visually." ${ }^{(8)}$ It is the visual quality which makes his shorts so special.

\section{Norman Maake}

The 25 year old Maake, a product of AFDA, received the Lionel Ngakane Award for the Most Promising filmmaker at the 2003 Cape Town World Cinema Festival. At Apollo in 2003 the jury gave him a special mention for his direction of Soldiers of the Rock. The film, in development and production since 1999, also won the Jury Prize at the Pan African Film and Arts Festival during 2004.

Personally I found the narrative about mine workers very problematic. It lacks a proper structure, the characterisation of protagonists and antagonists is inadequate and one never really understands the relationships between the various characters. But despite the messiness of the narrative structure there is a very promising director at work, sometimes creating sublime moments despite the content he has to work with.

I personally didn't like his short film, Home Sweet Home, for the same reasons: A lack of characterisation and a problematic narrative structure. But it was clear to me that from a directing point of view, here is a director at work with a strong visual sensibility. In retrospective the film will be remembered for its rugged kwaito soundtrack and no-holds-barred look at contemporary township life, an aspect which was for many years invisible on our screens during the apartheid era. ${ }^{(9)}$ The dialogue is also rich. Maake is currently working on his second feature film, The Other Side of London Bridge.

\section{Zulfah Otto-Sallies}

When one studies the first 100 years of South African cinema it is clear that the industry was extremely male dominated in terms of directors. Only a few female directors managed to make features (Katinka Heyns, Elaine Proctor, Helena Noguiera) and only in the 1990s were black female directors able to break into the industry (Palesa Nkosi, Xoliswa Sithole, Meganthrie Pillay and others). ${ }^{(10)}$

Zulfah Otto-Sallies is an important new female voice in South African cinema. Although her film career started only recently, her involvement in the other arts dates back to the 1980s - as writer, playwright and composer of musicals. Her musical Diekie vannie Bo-Kaap was presented at the Baxter Theatre in Cape Town and the Grahamstown National Arts festival. It was followed by even greater success: Productions such as Rosa, Koesiester Mentality, Echoes from the Ghettos and Rainbow and the Moon Princess played to full houses.

Her direct involvement in the film industry started at the Community Video Education Trust (CVET), of which she was the director during the mid 1990s. Her short, Raya, impressed me with its delicate portrait of three generations of women from the Bo-Kaap community, a world, which has been almost invisible in the past in South African cinema. In the 2003 edition of Variety's International Film Guide I called Raya "a visually beautiful insight into a closed, conservative community not often represented on our screens." Raya won an award at the Apollo Film Festival during 2000. 
Some of the themes of Raya are further explored in her documentary for Project 10,(11) namely Through the Eyes of My Daughter. Zulfah is fascinated by her fifteen-year-old daughter who, although she was born in the same neighbourhood as her mother, has developed an original view of the world. Mother and daughter get to know another in the documentary due to the intermediary of video.

Zulfah worked on a script entitled Mind the Gap, which further explores the "gap" between generations of women, and between modernity and tradition.

\section{Louis du Toit and New Afrikaner Voices}

Du Toit's short, When Tomorrow Calls (2003), about racial reconciliation, was chosen to launch the Commonwealth Film Festival in Manchester (2003) and it has been selected to tour the United Kingdom as part of the best of the shorts after the festival. After winning awards at the NTVA Stone Awards in 2002, the film was also selected for screening at the Short Ends World Film Schools Festival and at the Institute for Justice and Reconciliation's international conference in Cape Town last year.

The recognition of When Tomorrow Calls is well-deserved. In only eleven minutes the poetic and highly symbolic narrative depicts an old order of the apartheid years making way for a new dispensation of hope and Reconciliation in the story of an Afrikaans boy and a Xhosa boy facing each other as human beings. Shot in Afrikaans and Xhosa the film also depicts an Afrikaner nuclear family clearly characterised by the absence of the mother, and a father belonging to the past and unable to assist his son to adjust to the changing sociopolitical landscape of a post-apartheid South Africa.

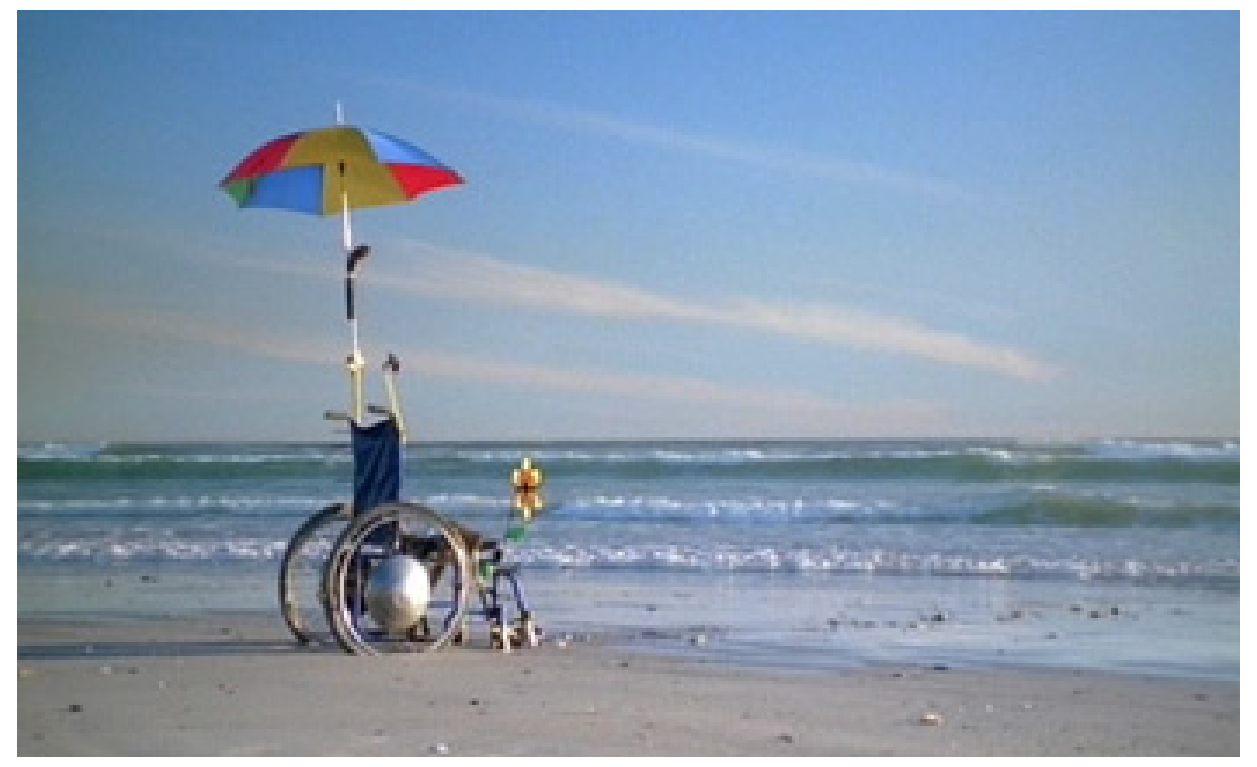

Figure 1: iBali (dir. Harold Holscher, 2003)

These cultural indicators are surprisingly also present in the Afrikaans short films of a new generation of directors: Rudi Steyn's Senter, J-H Beetge's Trionfeer, Danie Bester's Skitterwit and Johan Nel's Swing Left Frank. Despite working independently of each other, the same images of the Afrikaner nuclear family in a post-apartheid society appear in these exciting shorts, especially with regard to the absence of the Afrikaner mother! ${ }^{(12)}$ In particular, Nel's work is important as deliberate deconstructions of the soothing images of white Afrikaners in the cinema of the 1970s. With a few exceptions, Afrikaans language films ignored the socio-political turmoil of the period, as well as the realities experienced by black South Africans. Most Afrikaans language films communicated by means of obsolete symbols that had little multicultural communication value. They painted a one-sided and stereotypical portrait of the Afrikaner, leading to a misconception about who and what the Afrikaner was. Furthermore, the negative portrayal of blacks as a servant class in these films is a visual symbol of the deep-seated apartheid ideology. Nel has attempted to look at Afrikaners in all their ugliness and multi-facets: In a series of short films ranging from Malpit to his 
best, Swing Left Frank, the idealized image of the white Afrikaner is challenged and analyzed in a critical manner.

Louis du Toit, also a product of CityVarsity, is working on numerous scripts at the moment. One of them, a 30-minute short, 'n Roos vir Sara, further develops themes in When Tomorrow Calls.

\section{John Warner}

A graduate of CityVarsity Film, Television and Multimedia School in Cape Town, the 26-year-old John Warner has so far won no less than 11 local awards for his short films, music videos and advertisements. His greatest achievement to date is a short entitled Note to Self, which won the Gold and a craft award for directing at the 2001 NTVA Stone Awards ceremony. The film was screened in the official Ten Years of Democracy in South Africa retrospective at the $7^{\text {th }}$ Genova film festival and Warner was an invited guest.

Highly ambitious for a final year $35 \mathrm{~mm}$ student production, Note to Self is a surreal, almost Lynchian glimpse of the traumatic past still haunting our present. Two stories, one about a young man who kidnapped a girl, the other about two lovers who intend to meet for a Valentine's dinner, are seamlessly integrated into a dreamlike narrative. It is also a textbook of intertextuality: in only 12 minutes, references are made to Blue Velvet, The Cell, Wild at Heart and Natural Born Killers. But this postmodern piece remains Warner's own original vision and has been acknowledged as such by the juries, who gave him an award for his direction. Technically it surpasses the majority of final year student productions by local film schools. It has been selected in 2003 as one of the Best of RESFEST Africa and was screened in Durban, Cape Town and Johannesburg to very warm reception especially from young audiences. Wherever it has been screened in Cape Town, audiences were stunned by the technical quality and beauty of the surreal images.

Note to Self displays another characteristic in Warner's body of work, namely the deliberate subversion of movie genres. Throughout his shorts, Warner plays around with genre conventions and making references to various film examples. One of his shorts, for example, is a hilarious send-up of I know What You Did Last Summer. On a more serious note, in an evocative music video which features a black male choir singing a song about national reconciliation, Warner uses the Afrikaans Language monument at the Paarl as his setting. It becomes a very moving experience and the music video deservedly won an award in 2003 at the NTVA Stone Awards.

The road ahead is uncertain for Warner. At the moment he is working as a Personal Assistant at a company in Cape Town, but he has already written a few scripts for short and feature length films. One short especially has the same surreal qualities of Note to Self and one could but hope that a South African producer will commit himself/herself to this amazing talented new voice.

\section{Riaan Hendricks}

At the 2003 Sithengi $^{(13)}$ I saw by accident a documentary which was screened informally at the Cape Film Commission pavilion. I was immediately struck by the poetic beauty of $A$ Fisherman's Tale, a 26-minute personal narrative documentary film set in Kalkbay, Cape Town. It begins as the story of a young man who takes his father's fishing lines and goes out to sea in the hope of finding what the ocean means to the fishermen. The young man's story is addressed to his mother. But then the film takes another direction and becomes a moving reflection on the despair and hopelessness of these people's lives as globalization takes its effect, leaving entire South African subsistence fishing communities on dry land.

Structurally it is amazing to note how the personal narrative about the author's inability to communicate with his father, and the emotions that he could never articulate to his mother, is seamlessly integrated with the harsh conditions of the fishing community. With funding from the NFVF and the support of Encounters and CVET, Hendricks has realised this project after three hard years and in my opinion it deserves to be seen by all South Africans. As in the case of the Foster Brothers (Cosmic Africa, The Great Dance). ${ }^{(14)}$ Hendricks's documentary is enough proof that documentary work could be personal and poetic, and still succeed as non-fiction.

In-between assisting CVET with community-based video training programmes at the annual Apollo Film Festival, Hendricks is also working on a new project, namely Dream Young Lions Dream. The film structure and characters are very much still in development. In the description I received from Hendricks I have noted the poetic sensibilities of A Fisherman's Tale. The great scholar on African cinema, Prof. Mbye Cham of 
Howard University, remarked that A Fisherman's Tale has changed his notion of African cinema completely. I agree with him. Hendricks's film is a remarkable blend of personal reflection and social concerns.

\section{Sechaba Morojele}

Morojele is well-known in South Africa as an actor and writer, and actually needs no introduction. The reason why I have chosen him for this article is based on the fact that he is a walking example of what formal film training could do for an individual. After enrolling at the American Film Institute a few years ago he was awarded the Joseph and Olga Auerbach Scholarship and the Stan Kamen Endowed Scholarship for most deserving student. His script for Ubuntu's Wounds, a film about one man's disappointment with the Truth and Reconciliation Commission (TRC), was a quarter finalist in the New Century Writer's competition and also awarded the $\$ 10,000$ Martin Ritt Award that went towards the production of the film.

In his first year at the American Film Institute he made five short films and work on the first draft of Ubuntu's Wounds. This film is an excellent example of how a student film could launch the film career of an individual. Ubuntu's Wounds has already won the Best Short Film award at the Pan African Film Festival, as well as the Best Short in the Professional Category at the 2003 Apollo Film Festival.

Ubuntu's Wounds is a landmark in our post-apartheid cinema. While several local documentaries have dealt with the TRC, Morojele's film is the first attempt outside documentary film making to examine the effectiveness of the process and it questions whether real forgiveness is possible in response to truly inhuman acts. And it is a considerable achievement to raise and examine these questions in less than 35 minutes. The film also shows off Morojele as an actor's director, eliciting strong performances from his ensemble cast.

At the time of writing Morojele was working on a provocative documentary about the demystification of corporate South Africa.

\section{Madoda Ncayiyana}

Ncayiyana is actually a veteran of radio and television productions, as a director, producer and actor. He was the first black actor hired to work full-time in a South African performing arts council and the first black director of a Natal Performing Arts Council production. He has written and performed at theatre festivals throughout Europe and South Africa, including the Edinburgh festival, where one of his plays won the prestigious Scotsman Award, and South Africa's Grahamstown festival, where he has won awards for acting and writing. He was also the co-founder of Theatre for Africa in Johannesburg and the director of the Maningi Theatre Workshop of Durban.

He co-hosted a daily radio talk show with Julie Frederikse and co-wrote a book for young people entitled Careers in Media. His creative partnership with Frederikse dates back to 1993 when they began writing for radio and in 1995 co-hosted the daily national talk show. Since 1996 they have been writing together for television and Vuleka Productions was born.

Despite this formidable track record I have decided to include Madoda in this article because of his brilliant short film, The Sky in Her Eyes, which won the Djibril Diop Mambety Prize during 2003 at the Cannes film festival. The film, co-written, directed and produced by Madoda and Frederikse, has also been selected for screening at numerous international film festivals, including Sundance, Tampere, Siena and Banff, as well as at the United Nations General Assembly Special Session on Children. The film was shot on Super-16mm and developed and produced as part of Steps for the Future.

I saw the film a few years ago at a screening at Sithengi and then again as part of Ster-Kinekor's screening programme of local shorts before the main feature. I was immensely moved by its portrait of a young rural girl, left behind after her mother dies of AIDS. But again, as in the work of Riaan Hendricks, the poetic approach to a harsh reality impresses me and despite the short length of the film, I selected it as one of the year's best in my chapter on South Africa in Variety's International Film Guide 2003.

Madoda and Hendricks are two new poets of a post-apartheid cinema and hopefully their voices will be heard.

\section{Thabang Moleya}

Moleya is a final year film student at the CityVarsity Film, Television and Multimedia School. During 2003 he was a finalist with his Public Service Announcement (PSA) on blood transfusions at the Idba Film 
festival in Dubai, quite an achievement for a student, who had just finished his second year at film school! The PSA won for best creative editing in 2003 VUKA! Competition. He has been invited to attend the Berlin International Short Film Festival this year. He is also a finalist in the VUKA! Awards competition for 2004 and has been invited again to Dubai.

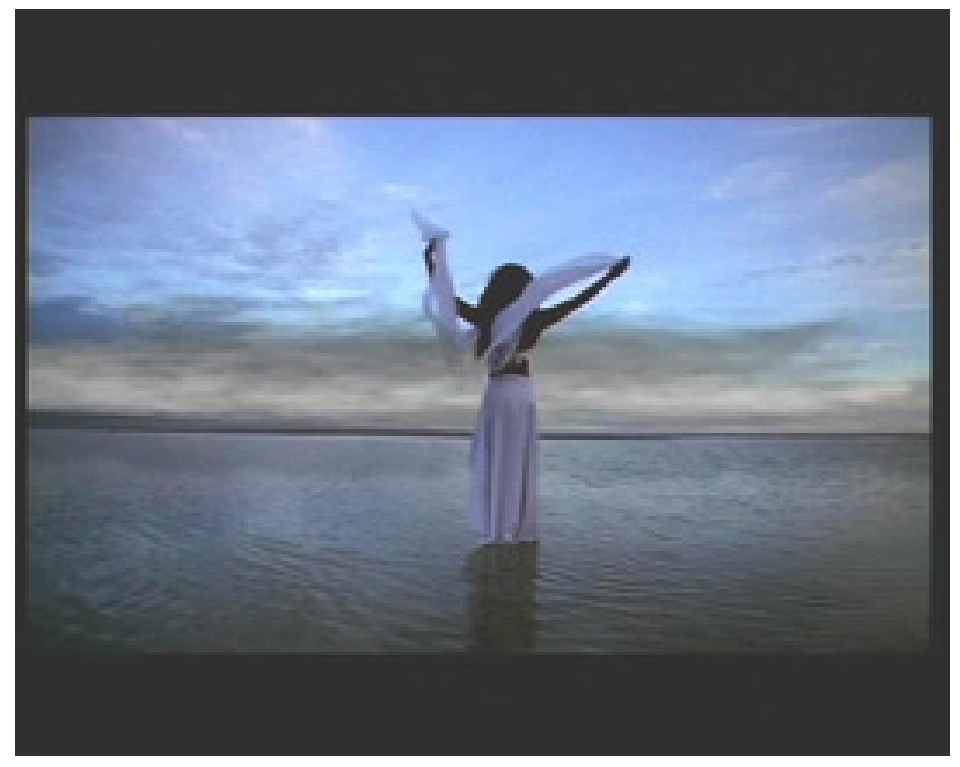

Figure 2: Swing Left Frank

And at the end of his first year at CityVarsity he impressed both lecturers and Capetonian audiences at NTVA meetings with his first short film, Room 302. As in the case of several other young filmmakers at the moment, Moleya examines the effects of our apartheid past on the psyche of South Africans. In Room 302 we, as an audience, are confronted with the post traumatic stress of a young white soldier, who did duty on the Border during the Namibian war. In expressionist black and white images, his psychological state is quite vividly portrayed and the story ends with a shooting. Appropriate references are made to the USA's invasion of Iraq and we draw parallels between this story and the trauma faced by many young American soldiers involved in that conflict. Moleya thus moves from an individual case to express a broader social concern about violence and the impact of war on the psyche of young men.

In his second year short film, Portrait of a Dark Soul, Moleya continues his examination of the impact of our past on our mental state: After a group of gangsters have failed in their attempts at a robbery, one of the members directs his frustration at a white woman, whom he associates with the past of white minority rule and black oppression. The consequences are devastating. There is a raw honesty to these short films and one notes Moleya's admiration for the work of Martin Scorcese (Good Fellas).

\section{Brian Little}

Little is also a graduate from CityVarsity and has started his own production company, employing various of his former classmates, including the remarkable Grant Appleton as Director of Photography. Appleton shot Swing Left Frank (see still earlier in this article) and 'n Sprokie, for which he received Craft awards from the National Television and Video Association (NTVA). Little's cinema is, like a large portion of post-apartheid cinema, a cinema of marginal voices. From his touching Soapbox to the impressive Tagged Toilets, the focus is on people on the margin.

\section{Conclusion}

For decades, South African film culture has been in isolation. The years 1959 to 1980 was characterised by an artistic revival in filmmaking throughout the world, ranging from exciting political films in Africa and Latin America to examples of great art cinema in Europe and Asia. National cinemas ${ }^{(15)}$ emerged in Australia, West Germany, Iceland and New Zealand. In 1977 Iceland, for example, was nearly invisible on the map of world cinema. Few films were made there, but since the establishment of a national film commission 
similar to our NFVF (National Film and Video Foundation) an independent cinema emerged. Following the establishment of the New Zealand Film Commission in 1978, 19 features were made over a period of five years, almost double the number of the previous eighty years.

Unfortunately, due to moral and political censorship, a severe lack of audience development and inadequate film distribution, South Africans and thus local filmmakers were not exposed to these remarkable developments in world cinema. We made hundreds of Afrikaans language soap operas instead during this time, while the world, including several African countries, explored the artistic, social and political possibilities of the medium to the fullest!

Film schools have thus become vital in a post-apartheid South African cinema to expose students to the highlights in the development of cinema in all its facets. Apart from skills training South African film schools have the responsibility to nurture new voices in an industry, which has a long history in which many voices were silenced - those from the black majority, women, gays and lesbians. ${ }^{(16)}$ Film is not only for getting bums on seats, but also a means of self-expression by voices, which were silent during the apartheid years. One could just look at three decades of African cinema to note the role played by film in the exploration of sociopolitical issues, popular memory, modes of communication and providing a space and a voice to those who never had the power in their representation on film.

At the moment film schools are dealing with this matter in very different ways. While AFDA is more inclined to use student films as a form of institutional branding, ${ }^{(17)}$ CityVarsity and the Cape Town International Film School, as well as Michaelis, a film school based at the University of Cape Town, are all actively encouraging the nurturing of directorial voices. Community-based film schools such as CVET and the Newtown Film School focus more on community video production, but are struggling to survive financially.

The National Film and Video Foundation (NFVF) has embarked on a national training strategy to investigate the needs of the film industry and to look at the role which could be played by all the existing film schools. For 94 years the voices of the majority of South Africans were oppressed in the cinema under apartheid. Now it is time to nurture these voices and allow them to be heard.

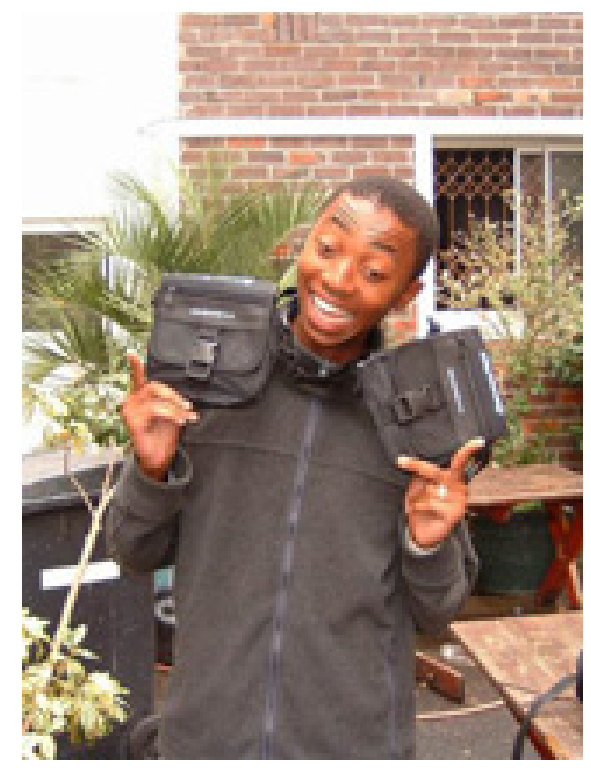

Figure 3: Thabang Moleya 


\section{Notes}

1. See publications by Blignaut \& Botha (1992), Gutsche (1972) and Tomaselli (1989).

2. Many film historians regard Jans Rautenbach as the pioneer of modern, bold and South African filmmaking during the 1960s and 1970s. Together with producer Emil Nofal he made groundbreaking films during a time when South African cinema hardly reflected the socio-political realities of the country. His work is examined in Tomaselli (1989) and Blignaut \& Botha (1992).

3. In the 1970s Devenish and playwright Athol Fugard created three highly acclaimed films, Boesman and Lena (1973), The Guest (1977) and Marigolds in August (1979). Boesman and Lena, based on Fugard's play, was the first local feature to portray the poverty and enforced removals of South Africans classified as "black" under apartheid. The Guest focuses on a small period in the life of Afrikaner intellectual, poet, writer and opium addict, Eugene Marais, going "cold-turkey" on a farm, called Steenkampskraal. Athol Fugard plays Marais as he staggers inevitably towards suicide. Devenish cuts incisively through the mythical stereotype of Marais, who believed that the existence of life is founded on pain and sorrow. This pain is the subject of a graceful, austere and controlled film, which handles its themes almost with musical skill. It is passed on and explored with almost a fugue-like pattern, from person to person, from voice to voice, until Marais' point seems irrefutable. Lastly, Marigolds in August portrays the tension between a poor, black man and an unemployed black man, who is struggling to support a family in a township near Port Elizabeth. The township is a place where malnutrition is rife. It is from this place that the one man walks every morning to work in the white beach resort. His security, however, is threatened by the presence of Melton, who is looking for work. The third of Devenish's collaborations with Athol Fugard, the film was one of the few local features in the 1970s, which examined the conditions of blacks in South Africa. It became an international award winner at various film festivals, including Berlin. See Tomaselli (1989), as well as Botha \& Van Aswegen (1992) for a discussion on his work.

4. See Botha, MP. 2003. "Homosexuality and South African cinema." Kinema No. 19 (Spring 2003):39-64. The article provides a history of the oppression of gay voices in a cinema under apartheid.

5. The Apollo Film Festival is held annually in the Northern Cape Town of Victoria West and highlights achievements in independent filmmaking in South Africa.

6. Production notes by Dean Blumberg.

7. Editor's note: This film won the Golden Bear at the 55th Berlinale in February 2005.

8. Interview with Harold Holscher, 2004.

9. See Balseiro, I. \& Masilela, N. (eds.) 2003. To change reels: Film and film culture in South Africa. Detroit: Wayne State University.

10. See Movies Moguls Mavericks: South African cinema: 1979-1991, pp. 233-254.

11. Screened all over the world Project 10, a series of documentaries which examine the personal experiences of ten years of democracy in South Africa, became a landmark in local documentary filmmaking. Project 10 was developed and commissioned by the public broadcaster SABC1 and supported by the NFVF, the Maurits Binger Institute and the Sundance Institute.

12. Valuable work on cultural indicators in Afrikaans cinema is done by Keyan Tomaselli and William Pretorius in the anthology on South African cinema, Movies Moguls Mavericks: South African cinema: 1997-1991.

13. Sithengi is the annual film market held in Cape Town. See http://www.sithengi.co.za

14. The Foster Brothers are internationally acclaimed documentary filmmakers. Their The Great Dance won over 20 international awards. Their latest feature is Cosmic Africa. Shot on High Definition this visual masterpiece explores and sheds light on traditional African astronomy. Using oral storytelling aesthetics the film vividly captures the remarkable personal journey of African astronomer, Thebe Medupe, through the ancestral land of Namibia's hunter-gatherers, the Dogon country of Mali and the landscapes of the 
Egyptian Sahara Desert. This seminal work swept eight awards at the 2003 National Television and Video Association's Stone Awards ceremony and received ecstatic acclaim at the Ten Years of Freedom festival in New York in 2004.

15. The concept "national cinema" is a complex one. Throughout history there has been a constant interaction between social organization and culture. By definition culture is a term which refers both to material production (artifacts) and to symbolic production (The aesthetic). In both instances, culture functions as the record and reflection of social history and the social process. Concepts of nation and national identity are also bound up in this socio-cultural functioning.

16. See Botha, MP. 2003. "Homosexuality and South African cinema." Kinema No. 19 (Spring 2003):39-64.

17. At the Zanzibar International Film festival in July 2004 Garth Holmes of AFDA participated in a panel discussion on film training in South Africa during the past decade. He stated that auteurism died with the French New wave of the 1960s and that the emphasis at AFDA is on collective filmmaking rather to encourage auteur directors. Many AFDA shorts have a distinctive "AFDA brand" almost like in the old Hollywood studio system.

\section{References}

Balseiro, I. \& Masilela, N. (eds.) 2003. To change reels: Film and film culture in South Africa. Detroit: Wayne State University.

Blignaut, J. \& Botha, MP. (eds.) 1992. Movies Moguls Mavericks: South African cinema 1979-1991. Cape Town: Showdata.

Botha, MP. 1997. My involvement in the process which led to the "White Paper on South African cinema." South African Theatre Journal 11(1\&2):269-285.

Botha, MP. 1998. Overview of South African cinema, in De role van de media in de multiculturele samenleving, edited by E Schelfhout \& H Verstraeten. Brussels: VUBPress.

Botha, MP. 2003a. Current film policy in South Africa: the establishment of the National Film and Video Foundation of South Africa and its role in the development of a post-apartheid film industry. Communicatio 29 (1\&2):182-198.

Botha, MP. 2003b. "Homosexuality and South African cinema." Kinema No. 19 (Spring 2003):39-64

Botha, MP. 2004. "The Song remains the same: The struggle for a South African film audience 1960-2003." Kinema No. 21 (Spring 2004):67-89.

Botha, M.P., Mare, L., Langa, Z., Netshitomboni, R., Ngoasheng, K., Potgieter, J. \& Greyling, M. 1994. Proposals for the restructuring of the South African film industry. Pretoria: Human Sciences Research Council.

Botha, MP. \& Dethier, H. 1997. Kronieken van Zuid-Afrika: De films van Manie van Rensburg. Brussel: VUB Press.

Botha, MP. \& Van Aswegen, A. 1992. Images of South Africa: The rise of the alternative film. Pretoria: Human Sciences Research Council.

Davis, P. 1996. In Darkest Hollywood: Exploring the jungles of cinema's South Africa. Randburg: Ravan.

Gutsche, T. 1972. The history and social significance of motion pictures in South Africa: 1895-1940. Cape Town: Howard Timmins.

Louw, PE \& Botha, JR. 1993. Film: the captivating power of fleeting images, in Mass media for the nineties: the South African handbook of mass communication, edited by AS de Beer: Pretoria: Van Schaik:151-172.

Shepperson, A. \& Tomaselli, KG. 2000. "South African cinema beyond apartheid: Affirmative action in distribution and storytelling." Social Identities. 6(3):323-324. 
Shepperson, A. \& Tomaselli, KG. 2002. Restructuring the industry: South African cinema beyond Apartheid. South African Theatre Journal. 16:63-79.

Tomaselli, K. 1989. The Cinema of Apartheid: Race and Class in South African Film. New York: Smyrna.

\section{Reports}

National Film and Video Foundation. 2001. Indaba 2001: Distribution, Exhibition and Marketing Report. Johannesburg: NFVF.

Nel, W. 2000. Profile 2000: Towards a viable South African Film Industry. Johannesburg: Pricewaterhouse Coopers.

South Africa. 1997. National Film and Video Foundation Act No. 73 of 1997. Pretoria: Government Printer.

\section{Author Information}

Martin P. BOTHA is Associate Professor of Film and Media Studies at the University of Cape Town. He has published more than 200 articles, reports and papers on South African media, including six books on South African cinema. His most recent book is South African Cinema 1896-2010 (Bristol: Intellect, 2012). 